Bayar, Y., Remeikiene, R., Androniceanu, A., Gaspareniene, L., \& Jucevicius, R. (2020). The Shadow Economy, Human Development and Foreign Direct Investment Inflows. Journal of Competitiveness, 12(1), 5-21. https://doi.org/10.7441/joc.2020.01.01

\title{
THE SHADOW ECONOMY, HUMAN DEVELOPMENT AND FOREIGN DIRECT INVESTMENT INFLOWS
}

\section{- Yilmaz Bayar, Rita Remeikiene, Armenia Androniceanu, Ligita Gaspareniene, Ramunas Jucevicius}

\begin{abstract}
During the past few decades, competition between countries has intensified. Every country seeks to become an essential player in international economic relations and take a prominent place in the world market. In this context, foreign direct investment inflows are accepted as a source of competitiveness through knowledge, know-how and technology transfer, but competitiveness is also accepted as a significant determinant of foreign direct investment attraction. Therefore, the specification of foreign direct investment inflow determinants is also important to improve competitiveness. In this research article, we aim to evaluate the impact of shadow economies and human development on foreign direct investment inflows as a possible determinant of competitiveness in 11 post-transition EU members over 1995-2015 period. The methodology employed in the applied section includes comparative and systematic literature analysis as well as second generation panel cointegration and causality analyses regarding both cross-sectional dependence and heterogeneity. The empirical analyses revealed that both the shadow economy and human development are significant determinants of foreign direct investment inflows. The causality analysis revealed a mutual interaction between foreign direct investment inflows and human development for all the countries in the sample, but a two-way causality between the foreign direct investment inflows and shadow economies only for Bulgaria, Croatia, and Romania and a one-way causality from shadow economies to the foreign direct investment inflows in the Czech Republic, Estonia, Hungary, Latvia, Lithuania, Poland, Slovakia, and Slovenia. The long-run analysis revealed that shadow economies negatively affected foreign direct investment inflows, while human development positively affected foreign direct investment inflows.
\end{abstract}

Keywords: competitiveness, shadow economy, buman development, foreign direct investment inflows, cointegration, causality analysis

JEL Classification: C33, E24, F21, F23

Received: November, 2019

1st Revision: January, 2020

Accepted: February, 2020

\section{INTRODUCTION}

Countries can gain new know-how, management skills, and production techniques through foreign direct investment (FDI) inflows (Blomström \& Kokko, 1998) and in turn raise their com- 
petitiveness and economic growth. Therefore, FDI is often considered an important engine that accelerates economic progress through know-how transfer and technological diffusion, raising competitiveness (Hunya, 2001; Bezic \& Karanikic, 2014; Osano \& Koine, 2016), the provision of the essential capital (Benhame, 2012) and higher productivity (Tintin, 2010; Davidescu \& Strat, 2015), in particular, in the countries with high absorptive capacities (e.g. with relatively open international trade and/or appropriate human resources) (Carbonell \& Werner, 2018). Furthermore, according to Auzina-Emsina et al. (2018) and Ivanová \& Čepel (2018), a country's competitiveness depends on many factors such as the internationalization process in enterprises, internet marketing activities, the personal skills of employees, globalization processes, trade liberalization, and foreign direct investment. Therefore, revealing the determinants of FDI inflows is important for the specification and implementation of appropriate policies to improve competitiveness and economic growth.

The related literature on the determinants of FDI inflows have focused on many economic, institutional, social, and cultural factors such as market size, economic growth, inflation, openness, labor costs, tax rate, infrastructure, political environment, government intervention level and property rights (Tocar, 2018). However the literature has generally disregarded the interaction among the FDI inflows, the shadow economy and human development. Given the positive effects of the FDI inflows, in this paper we focus on the influence of shadow economies and human development on these inflows

The phenomenon of the shadow economy is inherent to any country, and in accordance with its size it more or less significantly affects a country's social welfare and policies. Due to the multiple causes involves, including among these inefficient taxation, improper functioning of public institutions and excessive governmental interference in the labor and trade/service markets, a shadow economy jeopardizes the sustainable economic and social development of a country. As noted by Mara (2011), "The shadow economy affects the market functions as a phenomenon of erosion of the formal economy because speculate any opportunities generated by non-synchronization and indecision, following infiltration into any space left open by it."

Attempting to cover their budget deficits, the governments of the countries with large shadow economies may find it attractive to invoke FDI to potentially raise taxes on domestically sold goods and services as well as on international trade (Nikopour et al., 2009). At first glance, this attitude proposes that high shadow economies may cause higher inflows of FDI, especially keeping in mind that MNEs tend to invest in developing economies with ambiguous legislation, high corruption levels and tax havens (Okada \& Samreth, 2010; Davidescu \& Strat, 2015, Jones \& Temouri, 2016, etc.). On the other hand, some studies reveal that high shadow economies may discourage FDI due to the unacceptably high levels of business environment uncertainty caused by poor control and corruption (Tanzi, 2002; Castro \& Nunes, 2013; Fahad, 2016, etc.). The conclusions of the effects of FDI inflows on the shadow economy in a host country are also bidirectional: some studies (Deilami, 2010; Nikopour et al., 2009, etc.) propose that FDI may help foster a shadow economy, while others (e.g., Davidescu \&Strat, 2015) suggest that in encouraging FDI, MNEs bring with them higher standards of regulation compliance, which in turn may contribute to a reduction in the size of the shadow economy in a host country. However, previous studies have not provided unequivocal results concerning the causal relationship between FDI and shadow economies. 
Human development is also a significant determinant of competitiveness and economic growth, with FDI assumed to affect economic growth through the enhancement of human capital by education and training, along with the transfer of new information, know-how, and technology into the investee country (Li \& Liu, 2005; Majeed \& Ahmad, 2008; Agbola, 2013). However, human capital may contribute to FDI attraction, as FDI proceeds more readily in countries with relatively higher human capital development (Majeed \& Ahmad, 2008). Therefore, theoretically a two-way interaction between FDI and human development is expected, but the empirical studies conducted have been generally focused mainly on the impact of FDI on human development (Zhuang, 2017).

The present paper investigates the influence of shadow economies and human development on the FDI inflows for sample post-communist EU countries, and the article seeks to contribute significantly to the relevant literature in three ways. First, whereas certain factors regarding FDI inflows have been investigated extensively in the related literature, the shadow economy as a potential factor has been researched by relatively few scholars. Secondly, no studies on the interaction between the shadow economy and the FDI inflows have been conducted specifically for EU transition economies, therefore, the uniqueness of the study sample is another contribution of the paper. Lastly, the use of both a cointegration test and causality test regarding the crosssectional dependence and heterogeneity enable us to obtain more reliable results considering the relative lack of relevant empirical literature.

In the first part of the paper, a theoretical background regarding the relationships among a shadow economy, FDI and human development is presented, with the second section dedicated to the presentation of methodology, followed by the results of the empirical calculations in the third part of the article.

\section{THEORETICAL BACKGROUND}

The phenomenon of the shadow economy is complex and multifaceted, a situation caused by the many different determinants involved, among which the burden of taxes and social insurance contributions, along with the associated high level of bureaucracy and corruption, as well as inefficiency of regulatory and legal frameworks (Schneider, 2016; Medina \& Schneider, 2018; Remeikienè et al., 2018, etc.) are recognized as most influential.

In researching the links between a shadow economy and FDI, some authors focus on particular determinants of the former (e.g., corruption, tax avoidance, poor quality of public institutions), while others follow a more general approach. Among the previous findings concerning the links between a shadow economy and FDI, Nikopour et. al. (2009) for example have determined that in 145 countries, FDI instigated shadow economies, and vice versa during the years 1999-2005. Deilami (2010) examined how during 1999-2007 a higher FDI caused a higher shadow economy and vice versa in an analysis of 162 countries. Ali et al. (2010) discovered that the institutional quality positively affected FDI in manufacturing and service sectors in 69 countries. According to Peres et al. (2018), the institutional quality positively and significantly affected FDI in developed countries, but the impact on institutional quality on FDI in developing countries was insignificant. Lee \& Park (2013) found out that FDI are attracted to the countries with smaller shadow economies and stronger public institutions. According to Davidescu \& Strat (2015), in 
Romania, during 2000-2010, there existed an unidirectional short-run causality running from FDI to the shadow economy and the relationship between FDI and the shadow economy was negative in a short-run. The the relationship between corruption and FDI was negative in 48 countries (Hossain, 2016). Similar results have been obtained by Canare (2017) and Hakimi \& Hamdi (2017) in their studies: corruption had a negative effect on the FDI inflows and investment activities. In Ali \& Bohara (2017) study, a general approach to the links between FDI and the shadow economy is followed. Their findings indicate that, in general, the size of the shadow economy in a host economy relative to an investor's economy can significantly contribute to the attraction of FDI. The main methods used in calculations were the panel data Granger causality analysis, causality methods, GMM estimator, gravity model, Threshold effect model, standard panel regression model, Toda-Yamamoto causality, random effect model (REM), feasible general least squares method (FGLS), panels corrected standard errors (PCSE), correlation and variance inflation factor analysis.

While researching the links between the shadow economy and FDI in 145 countries, Nikopour et al. (2009) lean on the approach by which the phenomenon of the shadow economy is represented by corruption as by one of its key determinants. The authors explain their choice of the determinant stating that a high level of corruption leads to a decrease in a state's budget revenues: since operating under the conditions of high corruption, citizens do not want to contribute to budget revenues by paying all taxes, governments start offering privileges to foreign investors to promote FDI and thus offset the budget deficit. This view is shared by Fahad (2016), Javorcik \& Wei (2008), etc. Interestingly, different studies provide controversial results. The results of Nikopour et al. (2009) study propose that the shadow economy (represented by corruption) causes FDI, and vice versa, while Hossain (2016) finds a negative relationship between corruption and FDI (according to the latter, a one-percent decrease in the level of corruption may cause the FDI inflows to increase by $8.15,9.25$ and $11.5 \%$ estimated by employing REM, FGLS and PCSE methods respectively). Canare (2017), Navickas et al. (2016) research shows that corruption has a negative impact on the FDI inflows in general. Nevertheless, the author finds no significant relationship between the variables in low and middle income countries. The findings concerning the adversity of the effect of corruption on the FDI inflows are also confirmed by Sadig (2009) (who estimates that a one-point increase in the level of corruption causes the FDI inflows per capita to drop by about 11 percent), Hakimi \& Hamdi (2017), and many others.

Davidescu \& Strat (2015) as well as Deilami (2010) place the importance of their studies on tax avoidance which, in their opinion, significantly raises the capacity of capital to cross borders to escape the obligations of national taxation, and thus promotes investment in more favourable economic environment all over the world (as it was noted by Ali \& Bohara (2017), frequently, in tax heaven areas). Deilami's (2010) empirical results suggest that higher shadow economy causes higher FDI, and vice versa, whereas Davidescu \& Strat (2015) reveal a unidirectional shortrun causality, running from FDI to the shadow economy, and a short-run negative relationship between FDI and the shadow economy. The findings are explained proposing that FDI may stimulate a host economy and generate reforms in its taxation system.

Lee \& Park (2013) and Lee et al. (2018), who research the links between intellectual property rights (IPR), FDI and the shadow economy in developing countries, relate the shadow economy 
in terms of its effects on FDI to the poor quality of public institutions (poor quality of work of the public sector), proposing that the countries with weak and inefficiently working public institutions are not able to ensure effective protection of IPR. Their attitude is shared by Ali et al. (2010) who suggest that IPR protection is an extremely important determinant of FDI as FDI is indirectly affected by other institutional factors namely through IPR. Both - Lee \& Park's (2013) and Lee et al. (2018) - studies show that more intensive flows of FDI are attracted to the countries which are able to ensure stronger IPR protection, i.e. to the ones with smaller shadow economies and stronger public institutions. As it was noted by Lee et al. (2018), "in institutionally strong countries, IPR protection promotes FDI by reducing illegal imitation and freeing up more resources for MNCs". The importance of institutional quality for the FDI attraction is also confirmed by Peres et al. (2018) who provide the evidence that a high quality of public institutions positively affects the FDI inflows. Peres et al. (2018) estimations show that this effect is extremely strong in developed countries (one standard deviation change in institutional governance affects FDI by a factor of 0.2225 ), although it is insignificant in developing countries with weak institutional structures.

On balance, previous studies mainly analyze the relationship between FDI and the shadow economy by invoking such shadow economy determinants such as corruption, tax avoidance and institutional quality (in particular, in terms of IPR protection). The studies on the relationship between FDI and institutional quality provide least contradictory results and, in general, propose that smaller shadow economies with stronger public institutions, capable of protecting IPR, are able to attract more FDI inflows than larger shadow economies. The studies, focused on the relationship between FDI and tax avoidance, are much more contradictory and suggest that the links between the variables can either be positive or negative, bidirectional or unidirectional. The same applies to the studies addressing the links between FDI and corruption. It should also be noted that the relationship between FDI and the shadow economy may vary depending on the level of a country's development and trade openness.

Human capital is another important determinant underlying FDI inflows, but generally disregarded in the relevant literature, although the two variables may theoretically affect each other. The empirical studies on the effect of human capital proxied by different indicators such as illiteracy rate, primary/secondary/tertiary school enrolment rates, and human expenditures on the FDI attraction have remain inconclusive. In this context, Root \& Ahmed (1979), Schneider \& Frey (1985), and Narula (1996) revealed an insignificant relationship between human capital and the FDI inflows. However, relatively more studies revealed a significant relationship between human capital and FDI (Majeed \& Ahmad, 2008; Kim \& Park, 2013; Cleeve et al., 2015; Kheng et al., 2017). The relevant literature revealed that the studies investigating the interaction between human capital and the FDI inflows for early periods especially before 1980s reached the insignificant relationship between the variables, but the recent studies discovered a significant interaction between human capital and the FDI inflows. This contradiction was attributed to FDI composition, in other words, early FDI inflows concentrated on the industries requiring only cheap and unskilled labor but the recent FDI inflows have concentrated on technology intensive and service industries (Noorbakhsh et al., 2001; Dunning, 2002; Ritchie, 2002).

Majeed \& Ahmad (2008) explored the effect of human capital on the FDI attraction in 23 de- 
veloping countries over the period 1970-2004 and discovered that human capital positively affected the FDI inflows. On the other side, Kim \& Park (2013) researched the effect of human capital on FDI inflows in 63 countries over 1963-1998 and reached similar findings to Majeed \& Ahmad (2008). Cleeve et al. (2015) explored the effect of human capital on the FDI attraction in sub-Saharan Africa over 1980-2012 period and discovered that human capital was a significant positive determinant of the FDI attraction. Kheng et al. (2017) also investigated the mutual interaction between FDI and human capital in 55 developing countries during the period of 1980 2011 through simultaneous fixed effect estimation and revealed a two-way causality between FDI and human capital.

\section{AIM, METHODOLOGY AND DATA}

The main purpose of this article is to investigate the impact of shadow economy together with human development on the FDI inflows. To fulfil the defined purpose, the following objectives were set: 1) to review previous scientific findings on the relationship between FDI, shadow economy, and human development; 2) to select and substantiate the research methodology; 3) to provide results of the empirical research on the relationship between FDI and the shadow economy.

The article investigated the effect of shadow economy and human development on the FDI inflows in $11 \mathrm{EU}$ economies transited from centrally planned economies to market economies as of 1989 during the 1995-2015 period by panel cointegration and causality analyses.

The dependent variable of FDI inflows as percent of GDP was extracted from World Bank (2019). On the other side, human development was proxied by human development index of UNDP (2019) and the index is geometric mean of normalized indices for long and healthy life, knowledge, and living standard. Furthermore, shadow economy was represented by shadow economy size as a percent age of GPD through MIMIC method by Medina \& Schneider (2018). All the variables were annual and the the study period was determined as 1995-2015 due to the existence of shadow economy during the period of 1995-2015.

Tab. 1 - Data description. Source: own research

\begin{tabular}{|l|l|l|}
\hline Variables & Description & Source \\
\hline FDI & FDI, net inflows (\% of GDP) & World Bank (2019) \\
\hline SHA & Shadow economy size (\% of GDP) & Medina and Schneider (2018) \\
\hline HDI & Human development index & UNDP $(2019)$ \\
\hline
\end{tabular}

The sample of the econometric analysis consisted of Bulgaria, Croatia, the Czech Republic, Estonia, Hungary, Latvia, Lithuania, Poland, Romania, Slovakia, and Slovenia. The econometric analyses were implemented through the software of Stata 14.0 and Gauss 10.0. The main characteristics of the dataset were shown in Table 2. The average FDI was about $4.92 \%$ of GDP in the sample, but varied considerably from country to country. The the average shadow economy size was about $6.08 \%$ of GDP, but changed considerably among the countries. Lastly, average human development index was about 0.79 and did not change significantly in the sample. The minimum and maximum FDI inflows were respectively seen in Hungary, which was $-15.99 \%$ of GDP in 2010 and $50.50 \%$ of GDP in 2007 . The minimum size of shadow economy was seen as $10.47 \%$ 
of GDP in the Czech Republic in 2015, while the maximum size of shadow economy was seen as $37.33 \%$ of GDP in Croatia in 1995. The minimum human development index was seen as 0.63 in Latvia in 1995, while the maximum as 0.889 in Slovenia in 2015.

Tab. 2 - Summary statistics of the dataset. Source: own research

\begin{tabular}{|l|l|l|l|l|l|l|}
\hline Variables & Mean & $\begin{array}{l}\text { Std. Devia- } \\
\text { tion }\end{array}$ & Minimum & Maximum & Skewness & Kurtosis \\
\hline FDI & 4.93 & 5.99 & -15.99 & 50.50 & 1.98 & 7.16 \\
\hline SHA & 23.20 & 6.08 & 10.47 & 37.33 & -0.05 & 2.41 \\
\hline HDI & 0.79 & 0.05 & 0.673 & 0.89 & -0.31 & -0.31 \\
\hline
\end{tabular}

The cointegration relationship among the FDI inflows, shadow economy, and human development is analyzed through Westerlund \& Edgerton (2007) LM bootstrap cointegration test. The cointegration test is rest on the McCoskey \& Kao (1998) LM test and regards both cross-sectional dependence and heterogeneity. Furthermore, the test produces robust results for small samples. The cointegration test statistic is:

$L M_{N}^{+}=\frac{1}{N T^{2}} \sum_{i=1}^{N} \sum_{t=1}^{T} \widehat{w}_{i}^{-2} s_{i t}^{2}$

The $s_{i t}$ term in the above-mentioned equation represents the partial sum of error terms, while $\widehat{w}_{i}^{-2}$ is the long-run variance. Both terms are derived from the cointegration model estimated by a full, modified ordinary least squares method. For the test involving $L M_{N}^{+}$, critical values, bootstrapping should be employed in the event of a cross-sectional dependence among the series.

Lastly, the reciprocal interaction among the FDI inflows, shadow economy, and human development was analyzed with bootstrap Granger causality test of Kónya (2006) regarding both cross-sectional dependency and heterogeneity. Furthermore, the test is based on the Wald test with country-specific bootstrap critical values, so it does not require the joint hypothesis for all members of a panel. Lastly, it does not need any pre-testing and in turn is not exposed to the weaknesses resulting from the pre-tests.

\section{EMPIRICAL ANALYSIS}

In the econometric analysis, the first cross-sectional dependence was tested with the tests of LM (lagrange multiplier), LM CD (LM cross-section dependence) and LM adjusted and the test consequences were shown in Table 3. The null hypothesis suggesting the cross-sectional independence was denied at $1 \%$ significance level. So, the tests pointed out the presence of cross-sectional dependence among three series.

Tab. 3 - Results of cross-sectional dependency tests. Source: own research

\begin{tabular}{|l|l|l|}
\hline Test & Test statistic & P value \\
\hline LM (Breusch and Pagan(1980)) & 86.47 & 0.0043 \\
\hline LM adj. (Pesaran et al. (2008)) & 4.942 & 0.0000 \\
\hline LM CD & 6.103 & 0.0000 \\
\hline
\end{tabular}


Secondly, slope coefficients' homogeneity was tested with the adjusted delta tilde test of Pesaran \& Yamagata (2008) and the test consequences were shown in Table 4. The null hypothesis suggesting the existence of homogeneity was rejected in the light of $\mathrm{p}$ values of both tests. So, the slope coefficients of the cointegration equation were heterogeneous.

Tab. 4 - Results of homogeneity tests. Source: own research

\begin{tabular}{|l|l|l|}
\hline Tests & Test statistic & P value \\
\hline$\tilde{\Delta}$ & 1.444 & 0.074 \\
\hline$\tilde{\Delta}_{\text {adj. }}$ & 1.596 & 0.055 \\
\hline
\end{tabular}

The stationarity analysis of the series was examined with Pesaran (2007) CIPS (Cross-sectionally augmented IPS (Im et al., 2003) unit root test, taking notice of cross-sectional dependence and the test consequences were shown in Table 5. The test consequences revealed that all the series were I (1).

Tab. 5 - Results of CIPS unit root test. Source: own research

\begin{tabular}{|l|l|l|}
\hline Variables & Constant & Constant + Trend \\
\hline FDI & -0.641 & -0.895 \\
\hline D(FDI) & $-7.531^{*}$ & $-8.113^{*}$ \\
\hline SHA & -0.107 & -1.113 \\
\hline D $($ SHA $)$ & $-9.778^{*}$ & $-10.055^{*}$ \\
\hline HDI & -1.058 & -1.104 \\
\hline D(HDI $)$ & $-9.325^{*}$ & $-9.971^{*}$ \\
\hline
\end{tabular}

Optimum lag length was specified as 2, taking notice of Schwarz information criterion.

$*$ indicated that it is significant at $5 \%$

The cointegration relationship among FDI inflows, shadow economy, and human development was tested by Westerlund \& Edgerton (2007) LM bootstrap cointegration test considering the existence of cross-sectional dependence and the test consequences were shown in Table 6 . The null hypothesis suggesting the existence of cointegration relationship was accepted in two models. As a result, a significant long run relationship among the series was revealed.

Tab. 6 - Results of cointegration test. Source: own research

\begin{tabular}{|c|c|c|c|c|c|c|}
\hline \multirow{3}{*}{$\mathrm{LM}_{\mathrm{N}}^{+}$} & \multicolumn{3}{|c|}{ Constant } & \multicolumn{3}{|c|}{ Constant+Trend } \\
\hline & $\begin{array}{l}\text { Test } \\
\text { statistic }\end{array}$ & $\begin{array}{l}\text { Asymptotic } \\
\text { p value }\end{array}$ & $\begin{array}{l}\text { Bootstrap } \\
\text { P value }\end{array}$ & $\begin{array}{l}\text { Test } \\
\text { statistic }\end{array}$ & $\begin{array}{l}\text { Asymptotic } \\
\text { p value }\end{array}$ & $\begin{array}{l}\text { Bootstrap } \\
\text { P value }\end{array}$ \\
\hline & 9.234 & 0.189 & 0.296 & 10.324 & 0.214 & 0.329 \\
\hline
\end{tabular}

Note: Bootstrap critical values were 10,000 repeated simulations, while asymptotic p values were provided from standard normal distribution.

The cointegration coefficients were estimated by FMOLS (Full Modified OLS) estimator taking notice of heterogeneity and the test consequences were shown in Table 7 . The test consequences revealed that the shadow economy size negatively affected the FDI inflows overall panel, but human development had positive effects on the FDI attraction in the overall panel. 
However, the individual coefficients revealed that the impact of shadow economy and human development on the FDI inflows varied from country to country. The shadow economy size had the largest decreasing effect in Estonia and Bulgaria, while human development had the largest positive effect in Croatia and Latvia.

Tab. 7 - Results of cointegration coefficients' estimation. Source: own research

\begin{tabular}{|l|l|l|}
\hline Countries & Coefficients \\
\hline & SHA & HDI \\
\hline Bulgaria & $-0.047^{*}$ & $0.048^{*}$ \\
\hline Croatia & $-0.040^{*}$ & $0.069^{*}$ \\
\hline Czech Republic & $-0.037^{*}$ & $0.041^{*}$ \\
\hline Estonia & $-0.048^{*}$ & $0.048^{*}$ \\
\hline Hungary & $-0.032^{*}$ & $0.039^{*}$ \\
\hline Latvia & $-0.041^{*}$ & $0.056^{*}$ \\
\hline Lithuania & $-0.033^{*}$ & $0.059^{*}$ \\
\hline Poland & $-0.045^{*}$ & $0.025^{*}$ \\
\hline Romania & -0.028 & $0.053^{*}$ \\
\hline Slovakia & $-0.022^{*}$ & $0.048^{*}$ \\
\hline Slovenia & $-0.043^{*}$ & $0.046^{*}$ \\
\hline Panel & $-0.042^{*}$ & $0.057^{*}$ \\
\hline
\end{tabular}

$*$ indicated that it is significant at $5 \%$

The causal interaction among FDI inflows, shadow economy, and human development was tested by bootstrap panel Granger causality method of Kónya (2006) and the test consequences were shown in Table 8 and 9. The causality analysis revealed a two-way causality between FDI inflows and shadow economy in Bulgaria, Croatia, and Romania and a one-way causality from shadow economy to FDI inflows in the Czech Republic, Estonia, Hungary, Latvia, Lithuania, Poland, Slovakia, and Slovenia.

Tab. 8 - Results of causality test between FDI and SHA. Source: own research

\begin{tabular}{|l|l|l|l|l|l|}
\hline H0: SHA is not the cause of FDI \\
\hline \multirow{2}{*}{ Countries } & \multirow{2}{*}{ Wald statistic } & \multirow{2}{*}{$\begin{array}{l}\text { Bootstrap } \\
\text { p value }\end{array}$} & \multicolumn{4}{l}{ Critical values } \\
\cline { 4 - 7 } & & $\mathbf{\% 1}$ & $\mathbf{0 5}$ & $\mathbf{\% 1 0}$ \\
\hline Bulgaria & 17.049 & 0.028 & 20.385 & 14.360 & 9.963 \\
\hline Croatia & 26.231 & 0.013 & 21.217 & 17.602 & 9.345 \\
\hline Czech Republic & 21.440 & 0.037 & 17.034 & 12.064 & 8.636 \\
\hline Estonia & 20.239 & 0.006 & 18.461 & 16.460 & 7.973 \\
\hline Hungary & 20.852 & 0.015 & 23.957 & 10.163 & 9.080 \\
\hline Latvia & 23.049 & 0.000 & 20.760 & 13.878 & 10.479 \\
\hline Lithuania & 24.511 & 0.000 & 21.191 & 13.402 & 9.007 \\
\hline
\end{tabular}




\begin{tabular}{|c|c|c|c|c|c|}
\hline Poland & 27.796 & 0.023 & 18.151 & 16.502 & 8.886 \\
\hline Romania & 20.268 & 0.018 & 19.829 & 14.763 & 11.323 \\
\hline Slovakia & 24.574 & 0.000 & 15.389 & 11.016 & 7.533 \\
\hline Slovenia & 19.391 & 0.000 & 16.386 & 11.393 & 7.019 \\
\hline \multicolumn{6}{|c|}{ H0: FDI is not the cause of SHA } \\
\hline \multirow{2}{*}{ Countries } & \multirow{2}{*}{ Wald statistic } & \multirow{2}{*}{$\begin{array}{l}\text { Bootstrap } \\
\text { p value }\end{array}$} & \multicolumn{3}{|c|}{ Critical values } \\
\hline & & & $\% 1$ & $\% 5$ & $\% 10$ \\
\hline Bulgaria & 18.532 & 0.000 & 17.165 & 12.601 & 9.887 \\
\hline Croatia & 19.845 & 0.001 & 17.053 & 11.005 & 9.724 \\
\hline Czech republic & 6.337 & 0.142 & 14.849 & 12.094 & 8.402 \\
\hline Estonia & 5.112 & 0.176 & 11.965 & 10.532 & 8.384 \\
\hline Hungary & 7.154 & 0.093 & 13.652 & 9.677 & 6.271 \\
\hline Latvia & 6.453 & 0.149 & 10.131 & 8.284 & 7.821 \\
\hline Lithuania & 5.998 & 0.182 & 12.522 & 10.433 & 6.337 \\
\hline Poland & 6.225 & 0.072 & 15.693 & 9.358 & 7.278 \\
\hline Romania & 12.532 & 0.000 & 11.805 & 8.649 & 7.486 \\
\hline Slovakia & 6.445 & 0.334 & 15.146 & 8.671 & 6.924 \\
\hline Slovenia & 6.092 & 0.261 & 18.309 & 7.396 & 5.023 \\
\hline
\end{tabular}

A causality analysis between FDI inflows and shadow economies revealed a two-way causality between FDI inflows and shadow economies in Bulgaria, Croatia, and Romania, i.e. a mutual interaction between FDI inflows and the shadow economy in Bulgaria, Croatia, and Romania was indicated in the short run. However, a one-way causality of shadow economies to FDI inflows was revealed in the Czech Republic, Estonia, Hungary, Latvia, Lithuania, Poland, Slovakia, and Slovenia, i.e. the shadow economy had a significant effect on FDI inflows in the short run for these countries. Lastly, the causality analysis disclosed a two-way causality between FDI inflows and human development.

Tab. 9 - Results of causality test between FDI and HDI. Source: own research

\begin{tabular}{|l|l|l|l|l|l|}
\hline H0: HDI is not the cause of FDI \\
\hline Countries & Wald statistic & \multirow{2}{l}{$\begin{array}{l}\text { Bootstrap } \\
\text { p value }\end{array}$} & \multicolumn{4}{l|}{ Critical values } \\
\cline { 4 - 7 } & & $\mathbf{\% 1}$ & $\mathbf{\%} \mathbf{5}$ & $\mathbf{\% 1 0}$ \\
\hline Bulgaria & 17.421 & 0.001 & 15.307 & 10.734 & 9.301 \\
\hline Croatia & 20.286 & 0.032 & 19.860 & 14.613 & 9.131 \\
\hline Czech Republic & 14.200 & 0.005 & 11.373 & 10.017 & 8.377 \\
\hline Estonia & 20.385 & 0.016 & 19.505 & 15.111 & 10.172 \\
\hline Hungary & 14.217 & 0.003 & 10.443 & 9.079 & 8.045 \\
\hline Latvia & 13.034 & 0.026 & 11.832 & 10.632 & 7.575 \\
\hline Lithuania & 18.461 & 0.017 & 11.492 & 10.473 & 8.038 \\
\hline Poland & 17.957 & 0.000 & 13.802 & 12.394 & 8.301 \\
\hline
\end{tabular}




\begin{tabular}{|c|c|c|c|c|c|}
\hline Romania & 19.760 & 0.002 & 18.070 & 14.635 & 9.472 \\
\hline Slovakia & 17.191 & 0.019 & 15.134 & 11.289 & 9.882 \\
\hline Slovenia & 20.286 & 0.000 & 19.784 & 18.734 & 9.434 \\
\hline \multicolumn{6}{|c|}{ H0: FDI is not the cause of HDI } \\
\hline \multirow[t]{2}{*}{ Countries } & \multirow[t]{2}{*}{ Wald statistic } & \multirow{2}{*}{$\begin{array}{l}\text { Bootstrap } \\
\text { p value }\end{array}$} & \multicolumn{3}{|c|}{ Critical values } \\
\hline & & & $\% 1$ & $\% 5$ & $\% 10$ \\
\hline Bulgaria & 16.005 & 0.004 & 10.602 & 9.112 & 8.241 \\
\hline Croatia & 19.094 & 0.025 & 12.870 & 10.723 & 7.884 \\
\hline Czech Republic & 14.001 & 0.000 & 12.862 & 10.492 & 7.909 \\
\hline Estonia & 15.677 & 0.029 & 13.941 & 11.265 & 9.541 \\
\hline Hungary & 18.284 & 0.013 & 10.927 & 9.667 & 8.639 \\
\hline Latvia & 13.433 & 0.000 & 12.101 & 10.280 & 9.158 \\
\hline Lithuania & 19.358 & 0.007 & 13.633 & 12.170 & 8.316 \\
\hline Poland & 18.649 & 0.014 & 11.014 & 10.529 & 7.708 \\
\hline Romania & 18.671 & 0.024 & 12.823 & 10.360 & 7.963 \\
\hline Slovakia & 17.396 & 0.000 & 14.247 & 12.602 & 8.345 \\
\hline Slovenia & 15.842 & 0.003 & 11.889 & 9.170 & 7.316 \\
\hline
\end{tabular}

The causality analysis between human development and FDI inflows revealed that human development is a significant factor regarding FDI inflows in the short run, while FDI inflows are a significant determinant of human capital development. In other words, FDI inflows and human development foster each other in the short run.

\section{DISCUSSION}

The study aims to explore the influence of the shadow economy and human development on FDI inflows. The related literature about the interaction between FDI and the shadow economy remains inconclusive, but the institutional quality proxied by various indicators generally had a positive effect on FDI inflows. On the other hand, the effect of human development on FDI inflows varied depending on the type of FDI inflows. The FDI inflows including technology intensive and service industries generally preferred the destinations with higher human capital development.

This paper shows the results of an empirical analysis of the effect of the shadow economy and human development on the FDI inflows using a sample of post-communist economies for the period of 1995-2015 through Westerlund \& Edgerton (2007) LM bootstrap cointegration and Kónya (2006) bootstrap causality tests. The long-run effect of shadow economies and human development on FDI inflows was analyzed through a Westerlund \& Edgerton (2007) cointegration test, with the cointegration coefficients estimated by FMOLS. The panel coefficients revealed that the shadow economy size negatively affected the overall panel of the FDI inflows, but human development had positive effects on FDI attraction in the overall panel in a result compatible with the theoretical expectations. Nevertheless, the individual coefficients revealed 
that the impact of the shadow economy and human development on the FDI inflows varied from country to country, with shadow economy size having the largest decreasing effect in Estonia and Bulgaria, and human development showing the largest positive effect in Croatia and Latvia.

The negative long-run effect of the shadow economies on FDI inflows might have been made possible because each shadow economy generally resulted from a high tax and labor burden. Therefore, the shadow economies may have negatively affected FDI inflows if the additional costs from tax and labor issues were not eliminated by additional incentives for MNEs. Also, a company's decision to invest abroad is based on the interplay of market power, contractual uncertainties, intellectual property rights and other factors of international markets in terms of information. According to Lee et al. (2016), the quality of institutions effects FDI inflows into the host economy's country. In institutionally weak countries plagued by bureaucracy as well as corruption and government predation, FDI attraction is not as strong due to these problems. Furthermore, human capital quality is another important factor in FDI decisions, as MNEs need a given threshold of labor quality to carry out their activities. Therefore, higher human development is expected to positively influence FDI inflows, a result described in our paper.

The positive long-run effect of human capital development on FDI inflows could have been made possible depending on the type of FDI inflows. Furthermore, Majeed \& Ahmad (2008), Kim \& Park (2013), Cleeve et al. (2015) reached similar findings to our study.

Lastly, the causality analysis disclosed a reciprocal interaction between human development and FDI inflows 1 (Kheng et al., 2017). Human development triggered FDI inflows, while in turn FDI inflows led to an improvement in human development. On the other hand, the causality direction between the shadow economies and FDI inflows changed depending on the country. Along these lines, a mutual interaction between the shadow economies and FDI inflows was found in Bulgaria, Croatia, and Romania. However, the shadow economies were a significant determinant of FDI inflows in the Czech Republic, Estonia, Hungary, Latvia, Lithuania, Poland, Slovakia, and Slovenia in the short run.

\section{CONCLUSION}

International capital inflows have increased considerably with the contribution of liberalization and globalization processes during the past four decades. In this context, foreign direct investments with a long-term horizon in particular have caused many economic and non-economic effects in these countries. However, the distribution of FDI flows have change substantially among the countries, with flows to developing countries increasing steadily in recent years, and FDI flows to developed countries decreasing sharply as of 2015. This has caused many scholars to research the causes behind the differences in FDI flows, with many economic and non-economic factors revealed as determinants of FDI inflows. This study aims to make a contribution to the relevant literature by exploring the effects on FDI attraction through the second generation econometric tests of shadow economies and human development, factors which have been rarely researched.

The causality analysis revealed a mutual interaction between FDI inflows and human development for all the countries in the sample, but a two-way causality between FDI inflows and shad- 
ow economies only for Bulgaria, Croatia, and Romania, and a one-way causality from the shadow economies to FDI inflows in the Czech Republic, Estonia, Hungary, Latvia, Lithuania, Poland, Slovakia, and Slovenia. The long-run analysis revealed that the shadow economies negatively affected FDI inflows, while human development positively affected the inflows. Consequently, both the shadow economy and human development have been found as significant determinants of FDI attraction. In this context, institutional and regulatory arrangements contributing to the improvements regarding shadow economies will also foster FDI attraction. Furthermore, human development and FDI inflows show feedback loops with each other. On one hand, higher human development may cause more FDI attraction, on the other, FDI inflows may contribute to human development through the transfer of know-how, management and technology.

A limitation of the research was the time period of the study. This drawback was due to data availability and our disregard of the possible structural breaks of the econometric tests in the study period.

\section{References}

1. Agbola, F.W. (2013). Does human capital constrain the impact of foreign direct investment and remittances on economic growth in Ghana? Applied Economics, 45 (19/21), 2853-2862. https://doi.org/10.1080/00036846.2012.676735

2. Ali, M., \& Bohara, A. K. (2017). How does FDI respond to the size of shadow economy: an empirical analysis under a gravity model setting. International Economic Journal, 31 (2), 159-178. https://doi.org/10.1080/10168737.2017.1314533

3. Ali, F. A., Fiess, N., \& MacDonald, R. (2010). Do institutions matter for foreign direct investment? Open Economies Review, 21 (2), 201-219. https://doi.org/10.1007/s11079-010$9170-4$

4. Auzina-Emsina, A., Ozolina, V., \& Pocs, R. (2018). Competitiveness and economic development scenarios of Latvia. Business, Management and Education, 16 (1), 40-53. https:// doi.org/10.3846/bme.2018.2399

5. Benhame, M. (2012). Foreign direct investment and economic growth: Evidence from Southern Asia. Atlantic Review of Economics, 2, 1-14.

6. Bezic, H., \& Karanikic, P. (2014). Technology transfer, FDI and economic growth in the EU transition countries and the Republic of Croatia. Ekonomska Misao i Praksa, 23 (2), 463-482.

7. Blomström, M., \& Kokko, A. (1998). Multinational corporations and spillovers. Journal of Economic Surveys, 12 (2), 247-277.

8. Breusch, T. S. \& Pagan, A. R. (1980). The lagrange multiplier test and its applications to model specification tests in econometrics. Review of Economic Studies, 47 (1), 239-253. https:// doi.org/10.2307/2297111

9. Canare, T. (2017). The effect of corruption on foreign direct investment inflows: evidence from a panel of Asia-Pacific countries. In dela Rama, M., Rowley, C., The Changing Face of Corruption in Asia Pacific: Current Perspectives and Future Challenges, 35-55. https://doi. org/10.1016/B978-0-08-101109-6.00003-4 
10. Carbonell, J. B., \& Werner, R. A. (2018). Does foreign direct investment generate economic growth? A new empirical approach applied to Spain. Economic Geography, 94 (4), 425-456. https://doi.org/10.1080/00130095.2017.1393312

11. Castro, C., \& Nunes, P. (2013). Does corruption inhibit foreign direct investment? Polica, 51 (1), 61-83.

12. Cleeve, E.A., Debrah, Y., \& Yiheyis, Z. (2015). Human Capital and FDI Inflow: An Assessment of the African Case. World Development, 74 (1), 1-14. https://doi.org/10.1016/j. worlddev.2015.04.003

13. Davidescu, A. A., \& Strat, V. A. (2015). Shadow economy and foreign direct investments: an empirical analysis for the case of Romania. Ecoforum, 4 (2/7), 110-118.

14. Deilami, H. N. (2010). Relationships between shadow economy and foreign direct investment, growth and poverty. Retrieved from: http://psasir.upm.edu.my/id/ eprint/19471/1/FEP_2010_10_F.pdf

15. Dunning, J. H. (2002). Determinants of foreign direct investment: Globalization induced changes and the role of FDI policies. Background paper for the annual bank conference on development economics held in Oslo. Washington, DC: World Bank.

16. Fahad, A. Y. (2016). The impact of corruption on foreign direct investment (FDI) in pastconflict countries: a panel causality test. Journal of Advanced Social Research, 6 (3), 1-12.

17. Hakimi, A., \& Hamdi, H. (2017). Does corruption limit FDI and economic growth? Evidence from MENA countries. International Journal of Emerging Markets, 12 (3), 550-571. https://doi.org/10.1108/IJoEM-06-2015-0118

18. Hossain, S. (2016). Foreign direct investment (FDI) and corruption: is it a major hindrance for encouraging inward FDI? African Journal of Business Management, 10 (10), 256-269. https:// doi.org/10.5897/AJBM2016.8032

19. Hunya G. (2001) International Competitiveness: Impacts of Foreign Direct Investment in Hungary and Other Central and East European Countries. In: Meusburger P., Jöns H. (eds) Transformations in Hungary. Contributions to Economics. Physica, Heidelberg

20. Im, K.S., Pesaran M. H., \& Shin Y. (2003). Testing for unit roots in heterogeneous panels. Journal of Econometrics, 115 (1), 53-74. https://doi.org/10.1016/S0304-4076(03)00092-7

21. Ivanová, E., \& Čepel, M. (2018). The Impact of Innovation Performance on the Competitiveness of the Visegrad 4 Countries. Journal of Competitiveness, 10 (1), 54 -72. https://doi.org/10.7441/joc.2018.01.04

22. Javorcik, B. S., \& Wei, S. J. (2008). Corruption and cross-border investment in emerging markets: firm-level evidence. Retrieved from: https://www.cass.city.ac.uk/__data/assets/ pdf_file/0011/76970/Corruption-2008-06-19.pdf

23. Jones, C. \& Temouri, Y. (2016). The determinants of tax haven FDI. Journal of World Business, 51 (2), 237-250. https://doi.org/10.1016/j.jwb.2015.09.001

24. Kheng, V., Sun, S., \& Anwar, S. (2017). Foreign direct investment and human capital in developing countries: a panel data approach. Econ Change Restruct, 50 (1), 341-365. https:// doi.org/10.1007/s10644-016-9191-0 
25. Kim, J. \& Park, J. (2013). Foreign direct investment and country-specific human capital. Economic Inquiry, 51 (1), 198-210.

26. Kónya, L. (2006). Exports and Growth: Granger Causality Analysis on OECD Countries with a Panel Data Approach. Economic Modelling, 23 (6), 978-992.

27. Lee, M., Alba, J. D., \& Park, D. (2018). Intellectual property rights, informal economy, and FDI into developing countries. Journal of Policy Modelling, 40 (5), 1067-1081. https://doi. org/10.1016/j.jpolmod.2018.07.003

28. Lee, M., \& Park, D. (2013). Intellectual property rights, quality of institutions, and foreign direct investment into developing Asia. Retrieved from: https://www.adb.org/sites/default/ files/publication/30301/ewp-354.pdf

29. Lee, M., Alba, J. D., \& Park, D. (2016). Intellectual property rights, quality of institutions and FDI into developing countries. The 2016 WEI International Academic Conference Proceedings. Retrieved from: https://www.westeastinstitute.com/wp-content/ uploads/2016/03/Minsoo-Lee-Joseph-D.-Alba-Donghyun-Park.pdf

30. Li, X. \& Liu, X. (2005). Foreign direct investment and economic growth: an increasingly endogenous relationship. World Development, 33 (3), 393-407.

31. Majeed, M. T., \& Ahmad, E. (2008). Human capital development and FDI in developing countries. Journal of Economic Cooperation, 29 (3), 79-104.

32. Mara, E. R. (2011). Causes and consequences of underground economy. Retrieved from: https://mpra.ub.uni-muenchen.de/36438/1/MPRA_paper_36438.pdf

33. McCoskey, S., \& Kao, C. (1998). A residual-based test of the null of cointegration in panel data. Econometric Reviews, 17 (1), 57-84. https://doi.org/10.1080/07474939808800403

34. Medina, L. \& Schneider, F. (2018). Shadow economies around the world: What did we learn over the last 20 Years? IMF Working Paper WP/18/17

35. Narula, R. (1996). Multinational investment and economic structure: Globalization and competitiveness. London: Routledge.

36. Navickas, V., Navickas, M., \& Kordoš, M. (2016). Corruption effect on foreign direct investments in European Union countries. Business: Theory and Practice, 17 (4), 299-306. https://doi.org/10.3846/btp.17.10863

37. Nikopour, H., Habibullah, M. S., Schneider, F., \& Law, S. H. (2009). Foreign direct investment and shadow economy: a causality analysis using panel data. Retrieved from: https://mpra.ub.uni-muenchen.de/14485/1/MPRA_paper_14485.pdf

38. Noorbakhsh, F. Paloni, A. \& Youssef, A. (2001). Human capital and FDI inflows to developing countries: new empirical evidence. World Development, 29 (9),1593-1610.

39. Okada, K., \& Samreth, S. (2010). How does corruption influence the effect of foreign direct investment on economic growth? Retrieved from: https://mpra.ub.uni-muenchen. de/27572/1/MPRA_paper_27572.pdf

40. Osano, H. M., \& Koine, P. W. (2016). Role of foreign direct investment on technology transfer and economic growth in Kenya: a case of the energy sector. Journal of Innovation and Entrepreneurship, 5 (31), 1-25. https://doi.org/10.1186/s13731-016-0059-3 
41. Peres, M., Ameer, W., \& Xu, H. (2018). The impact of institutional quality on foreign direct investment inflows: evidence for developed and developing countries. Economic Research Ekonomska Instraživanja, 31 (1), 626-644. https://doi.org/10.1080/1331677X.2018.1438906

42. Pesaran, M. H. (2007). A simple panel unit root test in the presence of cross-section dependence. Journal of Applied Econometrics, 22 (2), 265-312. https://doi.org/10.1002/jae.951

43. Pesaran, M. H., \& Yamagata, T. (2008). Testing slope homogeneity in large panels. Journal of Econometrics, 142 (1), 50-93. https://doi.org/10.1016/j.jeconom.2007.05.010

44. Pesaran, M.H., Ullah, A., \& Yamagata, T. (2008). A bias-Adjusted LM test of error crosssection independence. Econometrics Journal, 11 (1), 105-127. https://doi.org/10.1111/j.1368423X.2007.00227.x

45. Remeikienè, R., Gasparènienė, L., Chadyšas, V., \& Cepel, M. (2018). Identification of the shadow economy determinants for the Eurozone member states: application of the MIMIC model. Journal of Business Economics and Management, 19 (6), 777-796. https://journals.vgtu.lt/ index.php/JBEM/article/view/6276

46. Ritchie, B. K. (2002). Foreign direct investment and intellectual capital formation in Southeast Asia. Technical paper no. 194. Paris: OECD Development Centre.

47. Root, F. R., \& Ahmed, A. A. (1979). Empirical determinants of manufacturing direct foreign investment in developing countries. Economic Development and Cultural Change, 27 (4), $751-767$.

48. Sadig, A. (2009). The effects of corruption in FDI inflows. Cato Journal, 29 (2), 267-294.

49. Schneider, F., \& Frey, B. S. (1985). Economic and political determinants of foreign direct investment. World Development, 13 (2), 161-175. https://doi.org/10.1016/0305750X(85)90002-6

50. Schneider, F. (2016). Estimating the size of the shadow economy in highly developed countries: selected new results. Retrieved from: https://www.ifo.de/DocDL/dice-report2016-4-schneider-december.pdf

51. Tanzi, V. (2002). The shadow economy, its causes and its consequences. Retrieved from: http://www.etco.org.br/user_file/shadowEconomy/03_Artigo_Tanzi_Shadow_Economy. pdf

52. Tintin, C. (2010). The impact of FDI on productivity and economic growth: a comparative perspective. Retrieved from: http://lup.lub.lu.se/luur/download?func=downloadFile\&reco rdOId $=1612761 \&$ fileOId $=1612772$

53. Tocar, S. (2018). Determinants of foreign direct investment: A review. Review of Economic and Business Studies, 11 (1), 165-196. https://doi.org/10.1515/rebs-2018-0069

54. UNDP (2019). Human Development Data (1990-2017). Retrieved from: http://hdr.undp. org/en/data (20.07.2019)

55. Westerlund, J., \& Edgerton, D. (2007). A panel bootstrap cointegration test. Economics Letters, 97 (1), 185-190.

56. World Bank (2019). Foreign direct investment, net inflows (\% of GDP). https://data. worldbank.org/indicator/BX.KLT.DINV.CD.WD (20.07.2019) 
57. Zhuang, H. (2017). The effect of foreign direct investment on human capital development in East Asia. Journal of the Asia Pacific Economy, 22 (2), 195-211. https://doi.org/10.1080/1354 7860.2016 .1240321

\section{Contact information}

Assoc. prof. dr. Yilmaz Bayar, Ph.D.

Usak University

Faculty of Economics and Administrative Sciences

Ankara Iżmir Yolu 8. Km Bir Eylül Kampüsü, Merkę/ Usak-Turkey

Turkey

E-mail:yilmazbayar@usak.edu.tr

ORCID:0000-0002-6776-6524

Assoc. prof. dr. Rita Remeikiene, Ph.D.

Mykolas Romeris University

Faculty of Economics and Business

Ateities str. 20, LT 08303 Vilnius Lithuania

Lithuania

E-mail: rita.remeikiene@mruni.eu

ORCID: 0000-0002-3369-485X

Prof. Armenia Androniceanu, Ph.D.

Bucharest University of Economic Studies

International Centre for Public Management, 11, Tache Ionescu, Bucharest, Romania

University of Social Sciences, 9 Sienkiewicza St. 90-113, Lodz, Poland

Romania

e-mail: socialsciences723@gmail.com

Prof. dr. Ligita Gaspareniene, Ph.D.

Mykolas Romeris University

Faculty of Economics and Business

Ateities str. 20, LT 08303 Vilnius Lithuania

Lithuania

E-mail: ligitagaspareniene@mruni.eu

ORCID: 0000-0002-5535-6552

Ramunas Jucevicius

Vilnius Gediminas Technical University

Faculty of Business Management

Law Department

Sauletekio al. 11, LT-10223 Vilnius

Lithuania

Email:ramunas.jucevicius@vgtu.lt 